\title{
Rozważania o rozszerzaniu się zakresu regulacji prawnorolnej z uwzględnieniem perspektywy notariusza
}

\section{Wprowadzenie}

Powszechnie znany jest dorobek Profesora Romana Budzinowskiego jako wybitnego teoretyka prawa rolnego ${ }^{1}$. Jednak Szanownemu Jubilatowi nie są też obce problemy praktycznego stosowania regulacji prawnorolnych, w szczególności stosowania ich przez notariuszy² ${ }^{2}$. Wyrażając głębokie uznanie Jubilatowi, niniejsze rozważania warto poświęcić stopniowemu rozszerzaniu zakresu regulacji zaliczanych do tradycyjnego prawa rolnego (prawa gruntowego) oraz wpływowi tego zjawiska na notarialną praktykę ich stosowania.

Do podjęcia badań w tym przedmiocie skłaniają obserwowane w ostatnich latach zmiany legislacyjne. Wejście w życie ustawy z 14 kwietnia 2016 r. o wstrzymaniu sprzedaży nieruchomości Zasobu Własności Rolnej Skarbu Państwa oraz o zmianie niektórych ustaw ${ }^{3}$ doprowadziło nie tylko do przy-

* Uniwersytet Jagielloński w Krakowie.

${ }^{1}$ Wśród wielu publikacji zob. w szczególności: R. Budzinowski, Problemy ogólne prawa rolnego. Przemiany podstaw legislacyjnych i koncepcji doktrynalnych, Poznań 2008; idem, Koncepcja gospodarstwa rolnego w prawie rolnym, Poznań 1992.

2 R. Budzinowski, Zbycie spadku obejmujacego gospodarstwo rolne w praktyce notarialnej, „Nowe Prawo" 1985, nr 7-8; idem, Umowa przekazania gospodarstwa rolnego następcy w praktyce notarialnej, „Nowe Prawo” 1986, z. 7-8; idem, Przekazanie gospodarstwa rolnego za rente strukturalnq w praktyce notarialnej, „Rejent” 2004, nr 10.

${ }^{3}$ Ustawa z 14 kwietnia 2016 r. o wstrzymaniu sprzedaży nieruchomości Zasobu Własności Rolnej Skarbu Państwa oraz o zmianie niektórych ustaw (t.j. Dz. U. z 2018 r., poz. 868 ze zm.; dalej u.w.s.n.). 
wrócenia praktycznego znaczenia przepisom ustawy z 11 kwietnia $2003 \mathrm{r}$. o kształtowaniu ustroju rolnego $0^{4}$, ale także do znaczącego rozszerzenia przedmiotu regulacji tego aktu prawnego. W konsekwencji unormowania u.k.u.r., tradycyjnie zaliczane do rolnego prawa gruntowego, stały się przedmiotem zainteresowania nie tylko prawników agrarystów, ale również specjalistów innych dziedzin prawa, o czym może świadczyć liczba publikacji i organizowanych konferencji o interdyscyplinarnym charakterze ${ }^{5}$. Co więcej, znaczenie obecnych regulacji u.k.u.r. nie ma wyłącznie wymiaru teoretycznego; przeciwnie, ustawa ta głęboko oddziałuje na praktykę stosowania prawa, a problemy związane z interpretacją jej unormowań istotnie wpływają na funkcjonowanie praktyków prawa, zwłaszcza notariuszy.

Celem niniejszego opracowania jest przedstawienie charakterystyki zarysowanej „ofensywy” regulacji prawnorolnych, tj. wpływu, jaki u.k.u.r. wywiera na regulacje niezaliczające się tradycyjnie do prawa rolnego oraz na notarialną praktykę obrotu nieruchomościami. Konieczne jest jednak zawężenie przedmiotu analiz do kwestii najbardziej ogólnych, ukazujących skalę oddziaływania u.k.u.r. na regulacje wolne dotychczas od jakichkolwiek form ,agraryzacji”. Tym zagadnieniom zostanie poświęcona pierwsza część opracowania. W drugiej części ukazany zostanie wymiar praktyczny regulacji u.k.u.r. poprzez przybliżenie niektórych problemów, z jakimi spotykają się notariusze, jako praktycy stosujący tę ustawę w swej codziennej działalności. Wybór tej profesji prawniczej nie jest przypadkowy, gdyż to właśnie notariusze najczęściej stają przed dylematami interpretacyjnymi wynikającymi z aktualnej redakcji przepisów u.k.u.r. Realizacja tego celu badawczego umożliwi dokonanie oceny opisanej „ofensywy” prawa rolnego gruntowego, poprzez wskazanie, czy rozszerzanie zakresu jego regulacji następuje w sposób racjonalny i spójny.

\section{O wpływie u.k.u.r. na inne dziedziny prawa - zagadnienie systemowej spójności regulacji prawnorolnych}

Jednym z zasadniczych założeń nowelizacji u.k.u.r. dokonanej w 2016 r. było odejście od wcześniejszej metody publicznoprawnej ingerencji w obrót nieruchomościami rolnymi, ograniczonej wyłącznie do reglamentacji umow-

${ }^{4}$ Ustawa z 11 kwietnia 2003 r. o kształtowaniu ustroju rolnego (t.j. Dz. U. z 2020 r., poz. 1655 ze zm.; dalej: u.k.u.r.).

${ }^{5}$ Dla przykładu, spośród wielu konferencji o takim charakterze można wymienić IX Kollokwium Jagiellońskie „Ograniczenia w obrocie nieruchomościami rolnymi”, zorganizowane przez Katedrę Prawa Cywilnego Uniwersytetu Jagiellońskiego w Krakowie 7 kwietnia 2017 r. 
nego obrotu własnościowego tą kategorią nieruchomości za pośrednictwem prawa pierwokupu i prawa nabycia przysługujących Agencji Nieruchomości Rolnych (ANR). Zakres stosowania u.k.u.r. w 2016 r. uległ istotnemu rozszerzeniu ${ }^{6}$, zyskując walor ogólnosystemowy - nieograniczony wyłącznie do tradycyjnie pojętego rolnego prawa gruntowego. Dla przykładu można wymienić kilka pól oddziaływania u.k.u.r. w jej aktualnym brzmieniu.

Wiele uwagi w literaturze prawniczej poświęca się wpływowi, jaki obecna regulacja prawnorolna wywiera na instytucję zasiedzenia ${ }^{7}$. Jest to związane z faktem dodania w 2016 r. do Kodeksu cywilnego przepisu art. 172 § , zgodnie z którym nieruchomość rolną $\mathrm{w}$ rozumieniu u.k.u.r. przez zasiedzenie może nabyć jedynie rolnik indywidualny (art. 6) i pod warunkiem, że ustalona zgodnie z przepisami art. 5 ust. 2 i 3 u.k.u.r. powierzchnia nabywanej nieruchomości rolnej wraz z nieruchomościami rolnymi stanowiącymi jego własność nie przekroczy 300 ha użytków rolnych. Należy podkreślić, że zgodnie $\mathrm{z}$ art. 14 u.w.s.n. reguła ta znajduje zastosowanie w przypadku, gdy termin zasiedzenia nieruchomości rolnej upłynął z dniem 30 kwietnia 2019 r. lub później. W następstwie wprowadzenia tej regulacji istotnemu ograniczeniu uległ krąg podmiotów uprawnionych do zasiedzenia nieruchomości rolnej. Wyłączona została m.in. możliwość zasiedzenia takiej nieruchomości przez jednostki organizacyjne, a możliwość jej zasiedzenia przez osoby fizyczne została uzależniona od spełnienia szeregu podmiotowych przesłanek składających się na definicję rolnika indywidualnego.

Brak spełnienia wymienionych przesłanek skutkuje z kolei wstrzymaniem zakończenia biegu terminu zasiedzenia, które nastąpi w dniu, gdy posiadacz samoistny będący osobą fizyczną spełni wymogi zakwalifikowania go jako rolnika indywidualnego ${ }^{8}$. W nielicznych przypadkach, gdy w drodze zasiedzenia nabywana jest przez rolnika indywidualnego nieruchomość, która nie jest położona $\mathrm{w}$ gminie miejsca jego zamieszkania ani w gminie graniczącej z tą gminą, aktualizuje się ponadto prawo nabycia Krajowego

${ }^{6}$ Z. Truszkiewicz, Zakres stosowania ustawy o ksztattowaniu ustroju rolnego po nowelizacji z 2016 r., ,Rejent” 2017, nr 7, s. 95-124.

7 J. Pisuliński, O niektórych osobliwościach obrotu nieruchomościami rolnymi, „Rejent” 2016, nr 5, s. 45-47; J. Biernat, Nabywanie nieruchomości rolnych w drodze zasiedzenia. Wybrane zagadnienia konstrukcyjne, „Studia Prawnicze. Rozprawy i Materiały” 2018, nr 1, s. 147-155; A. Bieranowski, Dekompozycja konstrukcji zasiedzenia w nowym reżimie ograniczeń nabycia własności nieruchomości rolnej - zagadnienia węzłowe i uwagi de lege ferenda, „Rejent” 2016, nr 5, s. 80-92; M. Balwicka-Szczyrba, O nabywaniu własności nieruchomości rolnych $w$ drodze zasiedzenia, „Gdańskie Studia Prawnicze” 2018 t. XXXIX, s. 221-230; eadem, Przesłanki nabycia nieruchomości rolnej w drodze zasiedzenia a ustrój wspólności majątkowej matżeńskiej, „Rejent” 2020, nr 8, s. 11-30.

${ }^{8}$ J. Pisuliński, O niektórych osobliwościach..., s. 46. 
Ośrodka Wsparcia Rolnictwa (KOWR) (art. 4 ust. 1 pkt 4 lit. a u.k.u.r.), wzbogacone o niezrozumiałą sankcję nieważności nabycia tej nieruchomości w wyniku uchybienia obowiązkowi zawiadomienia KOWR o przysługującym mu prawie nabycia. Te niespójne regulacje doczekały się w literaturze prawniczej jednoznacznie negatywnej oceny, w myśl której prowadzą one wręcz do „dekompozycji” samej konstrukcji zasiedzenia w prawie polskim ${ }^{9}$.

Innym szeroko dyskutowanym $\mathrm{w}$ literaturze problemem związanym $\mathrm{z}$ wpływem regulacji u.k.u.r. na tradycyjne instytucje prawa cywilnego jest znaczenie wynikających z postanowień tej ustawy zasad w przypadku tzw. zniesienia kauzy dla przeniesienia własności nieruchomości w rozumieniu ogólnych przepisów prawa cywilnego ${ }^{10}$. Problem ten dotyczy w szczególności wynikających z u.k.u.r.: zasady, że nabywcą nieruchomości rolnej może być jedynie rolnik indywidualny (art. 2a ust. 1 u.k.u.r.) oraz dwóch obowiązków nabywcy takiej nieruchomości, tj. nakazu prowadzenia gospodarstwa rolnego, w skład którego weszła nabyta nieruchomość rolna, przez okres co najmniej 5 lat od dnia nabycia przez niego tej nieruchomości, a w przypadku osoby fizycznej - prowadzenia tego gospodarstwa osobiście (art. 2b ust. 1 u.k.u.r.), oraz zakazu zbywania nabytej nieruchomości lub oddawania jej w posiadanie innym podmiotom $\mathrm{w}$ ramach tego samego 5-letniego okresu (art. $2 \mathrm{~b}$ ust. 2 u.k.u.r.). Zdaniem przedstawicieli nauki prawa cywilnego następstwem tych regulacji jest niemożność realizacji ochrony prawnej - również na drodze sądowej - zbywcy nieruchomości rolnej, np. w przypadku odstąpienia przez niego od umowy przeniesienia własności takiej nieruchomości lub odwołania jej darowizny, a także rozwiązania przez sąd umowy dożywocia, której przedmiotem była nieruchomość rolna ${ }^{11}$. I choć w nauce prawa trafnie próbuje się rozwiązać ten problem, wskazując, że zasady wynikające $\mathrm{z}$ art. 2a i $2 \mathrm{~b}$ u.k.u.r. nie powinny mieć w ogóle zastosowania do umów przenoszących własność nieruchomości rolnej zawieranych w celu wykonania zobowiązania, którego źródłem jest jednostronna czynność prawna niwecząca kauzę przeniesienia własności ${ }^{12}$, to kwestia ta daleka jest od jednoznacznego przesądzenia, skutkując dysfunkcjonalnością całego systemu prawnego ${ }^{13}$.

Jedną z najbardziej kontrowersyjnych regulacji wprowadzonych do u.k.u.r. w 2016 r. było formalne rozciągnięcie sankcji bezwzględnej nie-

9 J. Biernat, Nabywanie nieruchomości rolnych ..., s. 154; A. Bieranowski, Dekompozycja ..., s. 82.

${ }_{10} \mathrm{Z}$. Truszkiewicz, O kilku podstawowych zagadnieniach na tle ustawy o kształtowaniu ustroju rolnego (część II), „Rejent” 2017, nr 11, s. 24-26.

11 J. Pisuliński, O niektórych osobliwościach..., s. 34.

12 Z. Truszkiewicz, O kilku podstawowych zagadnieniach..., s. 26.

13 J. Pisuliński, O niektórych osobliwościach ..., s. 35. 
ważności, wynikającej z art. 9 ust. 1 u.k.u.r. i charakterystycznej dla konwencjonalnych czynności prawnych, na przypadki nabycia nieruchomości rolnej na podstawie prawomocnego orzeczenia sądowego wbrew przepisom u.k.u.r. (np. z naruszeniem art. 2 a ust. 1 tej ustawy) lub w razie uchybienia obowiązkowi zawiadomienia KOWR o przysługującym mu w takiej sytuacji prawie nabycia (art. 4 ust. 1 pkt 3 u.k.u.r.). Obecnie, choć nie doszło w tym względzie do ingerencji ustawodawcy, zasadniczo uznaje się powyższą regulację za nieporozumienie, wskazując, że prawomocne orzeczenie sądu, mocą którego doszło do nabycia własności nieruchomości rolnej, wiąże nie tylko strony i sąd, który je wydał, lecz także inne sądy oraz inne organy państwowe i organy administracji publicznej, w tym KOWR. Ponadto u.k.u.r. nie wprowadziła żadnych mechanizmów prawnych służących usunięciu z obrotu niezgodnego z nią orzeczenia - w szczególności nie mogą zostać wykorzystane w tym celu przewidziane w k.p.c. skargi o wznowienie postępowania oraz o stwierdzenie niezgodności z prawem prawomocnego orzeczenia, co oznacza, że KOWR nie ma podstaw, by kwestionować prawomocne orzeczenia sądowe skutkujące nabyciem własności nieruchomości rolnej z naruszeniem regulacji prawnorolnej ${ }^{14}$. Zastanawiające jest jednak to, że ustawodawca nadal wstrzymuje się z korektą tej nieszczęśliwej regulacji, która umożliwiłaby dopasowanie zasad wynikających z u.k.u.r. do polskiego systemu prawnego.

Unormowania u.k.u.r. wciąż natomiast mają znaczenie praktyczne w ramach postępowania egzekucyjnego. Choć w 2019 r. mocą ustawy z 26 kwietnia 2019 r. o zmianie ustawy o kształtowaniu ustroju rolnego oraz niektórych innych ustaw ${ }^{15}$ zliberalizowano reżim obrotu nieruchomościami rolnymi w postępowaniach egzekucyjnych, rezygnując z zasady, że nabywcą nieruchomości w ramach takiego postępowania może być wyłącznie rolnik indywidualny (art. 2 a ust. 3 pkt 9 u.k.u.r.), to nadal do nabywcy nieruchomości rolnej w toku egzekucji znajdują zastosowanie obowiązki określone $\mathrm{w}$ art. $2 \mathrm{~b}$ u.k.u.r. Rozwiązanie to zniechęca potencjalnych nabywców nieruchomości rolnych w ramach postępowań egzekucyjnych, uniemożliwiając efektywne zakończenie tych postępowań. Aktualne więc pozostaje spostrzeżenie, że nowelizując w 2016 r. u.k.u.r., przeoczono potrzebę ochrony praw osób trzecich, zwłaszcza wierzycieli wszczynających postępowanie egzekucyjne, podważając szanse zaspokojenia ich zasądzonych wierzytelności ${ }^{16}$.

${ }^{14}$ A.J. Szereda, Problematyka orzeczenia sadu w ustawie o ksztaltowaniu ustroju rolnego, „Krakowski Przegląd Notarialny” 2016, nr 4, s. 116.

${ }^{15}$ Ustawa z 26 kwietnia 2019 r. o zmianie ustawy o kształtowaniu ustroju rolnego oraz niektórych innych ustaw (Dz. U. poz. 1080).

${ }^{16}$ E. Gniewek, Nieruchomość rolna jako przedmiot egzekucji, „Rejent” 2017, nr 7, s. 22. 
Istotnym novum wprowadzonym przez nowelizację u.k.u.r. w 2016 r. było rozciągnięcie regulacji prawnorolnej na funkcjonowanie spółek handlowych będących właścicielami lub użytkownikami wieczystymi nieruchomości rolnych. Ingerencja ustawodawcy dotyczyła m.in. obrotu akcjami i udziałami w spółkach kapitałowych, w tym przypadków podwyższenia kapitału zakładowego (art. $3 \mathrm{a}$ i art. 4 ust. 6 u.k.u.r.), zmian personalnych wśród wspólników spółek osobowych (art. 3b u.k.u.r.) oraz sytuacji, w których dochodzi do nabycia nieruchomości rolnej w drodze podziału, przekształcenia bądź łączenia spółek prawa handlowego (art. 4 ust. 1 pkt 4 lit. b u.k.u.r.). Wprowadzenie nowych regulacji spotkało się ze sporym oddźwiękiem w piśmiennictwie, nie tylko zresztą agrarystycznym, ale również w nauce prawa gospodarczego i handlowego ${ }^{17}$. Trudno w tym miejscu wymienić wszystkie zarzuty podnoszone w licznych publikacjach co do niespójności regulacji u.k.u.r. z fundamentalnymi zasadami prawa spółek, jak również z dotychczasowym dorobkiem doktryny i orzecznictwa w zakresie prawa handlowego. Dotyczą one zarówno kwestii najbardziej ogólnych, takich jak np. uznanie, że w przypadku przekształcenia spółki handlowej będącej właścicielem nieruchomości rolnej dochodzi do nabycia tej nieruchomości, wbrew powszechnie przyjętej na płaszczyźnie prawa handlowego zasadzie, że przekształcenie spółki nie prowadzi do zmiany podmiotowej, a jedynie do formalnej wewnętrznej reorganizacji spółki ${ }^{18}$, jak i zagadnień zdecydowanie bardziej szczegółowych. Do tych ostatnich należy zaliczyć szereg problemów związanych z podwyższeniem kapitału w spółce kapitałowej. Odno-

17 Zob. np.: J. Grykiel, Ograniczenia obrotu nieruchomościami rolnymi oraz prawami udziatowymi w spótkach po nowelizacji ustawy o ksztattowaniu ustroju rolnego, „Monitor Prawniczy” 2016, nr 12, s. 628-629; Sz. Byczko, Ustawowe prawo pierwokupu udziałów i akcji spółek będacych właścicielami nieruchomości rolnych, w: P. Księżak, J. Mikołajczyk (red.), Nieruchomości rolne w praktyce notarialnej, Warszawa 2017, s. 236-246; J. Bieluk, Zastaw na udziałach i akcjach w spótkach będacych właścicielami lub użytkownikami wieczystymi nieruchomości rolnych - paradoks art. 3 a ust. 3 a ustawy o ksztaltowaniu ustroju rolnego, „Przegląd Prawa Rolnego” 2021, nr 1, s. 59-68; idem, Przekształcenia spótek kapitałowych a ustawa o kształtowaniu ustroju rolnego, „Przegląd Prawa Rolnego” 2019, nr 2, s. 113-124; M. Muszalska, Spótki handlowe a znowelizowana ustawa o ksztaltowaniu ustroju rolnego - uwagi z praktyki notarialnej, „Studia Prawa Publicznego" 2020, nr 4, s. 63-86; D. Buszmak, W. Kocot, Przekształcenie spótki handlowej będącej wtaścicielem nieruchomości rolnej, „Przegląd Prawa Handlowego” 2017, nr 7, s. 4-11; J. Stranz, Wplyw nowelizacji ustawy o kształtowaniu ustroju rolnego na procedurę podwyższania kapitału zakładowego spółki akcyjnej, „Przegląd Prawa Handlowego” 2016, nr 12, s. 5-9.

18 D. Buszmak, W. Kocot, Przekształcenie..., s. 4. Ostatecznie jednak w orzecznictwie i literaturze górę wziął pogląd, że „nabycie nieruchomości rolnej w wyniku przekształcenia spółki handlowej jest nabyciem w wyniku zdarzenia prawnego, o którym mowa w art. 2 pkt 7 ustawy z 2003 r. o kształtowaniu ustroju rolnego". Por. wyrok NSA z 15 stycznia 2019 r., II OSK 306/18; J. Bieluk, Przeksztatcenia ..., s. 114. 
szą się one np. do kwestii objęcia reglamentacją u.k.u.r przypadków, gdy w podwyższeniu kapitału uczestniczą wyłącznie dotychczasowi wspólnicy spółki oraz gdy podwyższenie kapitału następuje w drodze podwyższenia wartości nominalnej udziałów lub akcji ${ }^{19}$. Dalsze wątpliwości wywołuje rodzaj uprawnień przysługujących KOWR w sytuacji, gdy do podwyższenia kapitału zakładowego dochodzi poprzez wniesienie aportu w postaci nieruchomości rolnej ${ }^{20}$. Niejasna pozostaje też kwestia sankcji za uchybienie obowiązkowi zawiadomienia KOWR o możliwości skorzystania z prawa nabycia (nieruchomości lub udziałów i akcji) w razie podwyższenia kapitału zakładowego, w świetle ogólnej reguły k.s.h., według której do podwyższenia kapitału dochodzi w następstwie wpisu podwyższenia do KRS, tj. w wyniku postanowienia sądu, a nie w drodze czynności prawnej ${ }^{21}$.

Abstrahując od technicznych zagadnień, wątpliwości może budzić sama pozycja spółek handlowych jako nabywców nieruchomości rolnych na płaszczyźnie u.k.u.r. Z jednej strony spółki zostały dopuszczone do ich nabywania, choć na warunkach mniej korzystnych niż osoby fizyczne, bowiem niemożliwe jest uzyskanie przez nie statusu rolnika indywidualnego i związanych z tym przywilejów. Z drugiej strony spółki te zostały objęte powszechnymi obowiązkami ciążącymi na nabywcach nieruchomości rolnych, tj. w szczególności 5-letnim obowiązkiem prowadzenia gospodarstwo rolnego, w skład którego weszła nabyta nieruchomość rolna. W myśl dominującej w obrocie wykładni obowiązek ten dotyczy także spółek niemających do tej pory jakichkolwiek związków z rolnictwem, a jego niedochowanie sankcjonowane jest możliwością przepadku nabytej nieruchomości na rzecz Skarbu Państwa (art. 9 ust. 3 u.k.u.r.) 22. Rozwiązanie to wraz z niektórymi innymi regulacjami u.k.u.r. ${ }^{23}$ silnie negatywnie oddziałuje na funkcjonowanie

${ }^{19} \mathrm{~W}$ tym bowiem przypadku, choć stosownie do art. 4 ust. 6 u.k.u.r. KOWR powinno formalnie przysługiwać prawo nabycia, pojawia się problem z określeniem przedmiotu tego prawa.

${ }^{20}$ Wątpliwości budzi kwestia, czy sytuacja ta objęta jest jedynie ogólnymi regulacjami u.k.u.r określającymi zasady nabywania nieruchomości rolnych (art. 2a u.k.u.r. i art. 4 ust. 1 u.k.u.r), czy prowadzi ponadto do aktualizacji uprawnienia KOWR wynikającego $\mathrm{z}$ art. 4 ust. 6 u.k.u.r., czyli prawa nabycia, którego przedmiotem są akcje i udziały w podwyższonym kapitale zakładowym. Por. J. Bieluk, Przeksztatcenia ..., s. 116-117.

${ }^{21}$ Ibidem, s. 121.

${ }^{22}$ Szerzej: P.A. Blajer, Z prawnej problematyki obowiązków nabywcy nieruchomości rolnej wynikających $z$ art. 2 b ustawy o ksztaltowaniu ustroju rolnego, „Przegląd Prawa Rolnego” 2021, nr 1 , s. 33 i n.

${ }^{23}$ Mowa tu przede wszystkim o rozwiązaniu, w myśl którego niemal każda zmiana składu osobowego spółki handlowej, będącej właścicielem lub użytkownikiem wieczystym nieruchomości rolnej o powierzchni co najmniej 5 ha stanowi zagrożenie dla jej bytu z uwagi na możliwość utraty nieruchomości, stanowiącej często najważniejszy składnik majątku spółki (art. 3 b ust. 1 u.k.u.r.), lub ryzyka związane z nabyciem akcji lub udziałów przez KOWR działający na rzecz Skarbu Państwa 
spółek handlowych będących właścicielami lub użytkownikami wieczystymi nieruchomości rolnych.

Problematyka oddziaływania regulacji u.k.u.r. na postępowania upadłościowe i restrukturyzacyjne nie doczekała się dotąd szerszej analizy w literaturze ${ }^{24}$, mimo że ustawa ta wywiera istotny wpływ na możliwość realizowania zasadniczych celów wymienionych postępowań. Wystarczy wspomnieć, że choć nowelizacja u.k.u.r. z 2019 r. wyeliminowała istotny problem praktyczny, jakim było objęcie regulacją art. 2a tego aktu prawnego przypadków nabycia nieruchomości rolnej w toku postępowania upadłościowego (art. 2a ust. 3 pkt 9 u.k.u.r.), to ze względu na treść art. 2a ust. 3 pkt 4 u.k.u.r. wynikające $\mathrm{z}$ tego przepisu ograniczenie kręgu nabywców nieruchomości rolnych o obszarze co najmniej 1 ha nadal znajduje zastosowanie do przypadków nabycia nieruchomości rolnej w toku postępowania restrukturyzacyjnego, innego niż postępowanie sanacyjne. Jednak zasadniczy problem ze stosowaniem u.k.u.r. do wymienionych postępowań zdaje się tkwić gdzie indziej. Należy bowiem przypomnieć, że wymienione postępowania prowadzi się przede wszystkim wobec przedsiębiorców w rozumieniu k.c. (por. art. 5 ust. 1 ustawy z 28 lutego 2003 r. Prawo upadłościowe ${ }^{25}$ ), w związku z czym przedmiotem sprzedaży w ramach tych postępowań często jest przedsiębiorstwo $\mathrm{w}$ rozumieniu art. $55^{1}$ k.c. (por. art. 316 pr. upad.). Unormowanie to otwiera $\mathrm{z}$ kolei pole do rozważań, czy przepisy u.k.u.r. powinny znaleźć zastosowanie w przypadku, gdy w skład przedsiębiorstwa wchodzi nieruchomość rolna w rozumieniu tej ustawy. Odpowiedź pozytywna na to pytanie skutkuje jednak trudnościami z określeniem przedmiotu prawa pierwokupu KOWR (art. 3 ust. 4 u.k.u.r.).

$\mathrm{W}$ aktualnym stanie prawnym nie ma bowiem podstaw, by nieruchomość rolną wchodzącą w skład przedsiębiorstwa wyłączać z tego przedsię-

(art. 3a i 4 ust. 6 u.k.u.r.). Wątpliwości budzi ponadto uprawnienie KOWR do przeglądania ksiąg i dokumentów spółki oraz żądania od tej spółki informacji dotyczących obciążeń i zobowiązań nieujętych w księgach i dokumentach (art. 3a ust. 3 u.k.u.r.), niezależnie od tego, czy KOWR rzeczywiście zamierza nabyć jej udziały lub akcje. Rozwiązanie to ocenia się w literaturze jako niedopuszczalną ingerencję podmiotu trzeciego w sferę tajemnic i spraw wewnętrznych spółki, bez względu na istniejące obawy o wykorzystanie powziętych informacji w celach sprzecznych z interesem spółki. Por. M. Bidziński, M. Chmaj, B. Ulijasz, Ustawa o wstrzymaniu sprzedaży nieruchomości Zasobu Własności Rolnej Skarbu Państwa - aspekt konstytucyjnoprawny, Torun 2017, s. 158.

${ }^{24}$ E. Marszałkowska-Krześ, I. Gil, Wpływ wszczęcia postępowań restrukturyzacyjnych na obrót nieruchomościami rolnymi, w: P. Księżak, J. Mikołajczyk (red.), Nieruchomości rolne w praktyce notarialnej, Warszawa 2017, s. 223-235.

${ }^{25}$ Ustawa z 28 lutego 2003 r. Prawo upadłościowe (t.j. Dz. U. z 2020 r., poz. 1228, dalej: pr. upad.). 
biorstwa i poddawać oddzielnej sprzedaży z uwzględnieniem pierwokupu KOWR (por. art. 319 ust. 5 pr. upad. w jego oryginalnej wersji). Z drugiej strony przyznanie KOWR pierwokupu do całego przedsiębiorstwa byłoby sprzeczne z celami u.k.u.r. przewidzianymi w preambule i zasadami kształtowania ustroju rolnego określonymi w art. 1 u.k.u.r. Trudno również sobie wyobrazić, na czym w tym wypadku miałaby polegać realizacja obowiązku prowadzenia gospodarstwa rolnego wynikająca $\mathrm{z}$ art. $2 \mathrm{~b}$ ust. 1 u.k.u.r. Nawet jednak w przypadku, gdy przedmiotem sprzedaży w toku postępowania upadłościowego lub restrukturyzacyjnego jest nieruchomość rolna niewchodząca w skład przedsiębiorstwa, objęcie nabywcy takiej nieruchomości uniwersalnymi obowiązkami wynikającymi z art. 2 b u.k.u.r. może stanowić czynnik zniechęcający potencjalnych nabywców, a tym samym skutkujący niemożnością realizacji celów tych postępowań.

Reasumując dotychczasowe rozważania nad oddziaływaniem aktualnych regulacji prawnorolnych zawartych $w$ u.k.u.r. na inne dziedziny prawa, należy zauważyć, że wpływ ten, choć istotny, trudno uznać za pozytywny. Zwraca uwagę nieudana próba wtłoczenia tradycyjnych instytucji i pojęć prawnorolnych, takich jak nieruchomość rolna, gospodarstwo rolne, działalność rolnicza czy prowadzenie gospodarstwa rolnego, w konstrukcje i instrumenty prawne charakterystyczne dla odmiennych stosunków społecznych, będących przedmiotem regulacji innych dziedzin prawa. W konsekwencji przytoczone wyżej regulacje wykazują systemową niespójność. Jest to efektem pośpiechu i niedbałości ustawodawcy, rezygnującego z pogłębionej refleksji teoretycznej nad skutkami rozwiązań wprowadzanych w całym systemie prawa w Polsce. W tym kontekście warto zauważyć, że regulacje prawnorolne stają się narzędziem publicyzacji innych dziedzin prawa. Są bowiem wykorzystywane do poddania publicznej kontroli stosunków społecznych jeszcze nią nieobjętych, a często mających z rolnictwem związek jedynie formalny.

\section{Wzrost znaczenia regulacji prawnorolnej w praktyce notarialnej}

Te ogólne teoretyczne uwagi skłaniają do przyjrzenia się problemowi zarysowanej „ofensywy” rolnego prawa gruntowego z perspektywy działalności prawników, którzy z regulacjami u.k.u.r. mają najczęściej do czynienia, tj. notariuszy. Trudno bowiem zaprzeczyć, że rozszerzenie przedmiotu regulacji u.k.u.r. w 2016 r. spowodowało niebywały wzrost zainteresowania problematyką prawnorolną w tej grupie zawodowej, czego dowodem mogą być liczne wykłady i konferencje szkoleniowe kierowane do przedstawicieli 
tego zawodu ${ }^{26}$. Ostatni raz problematyka prawnej reglamentacji obrotu nieruchomościami rolnymi odnosiła się bowiem w tak szerokim zakresie do działalności notariuszy w latach 80 . XX w. ${ }^{27}$ Lata 90 . to całkowity odwrót od dotychczasowej surowej publicznoprawnej kontroli obrotu, zgodnie z dominującymi w owym okresie koncepcjami liberalnymi. Z kolei regulacje u.k.u.r. w jej pierwotnym brzmieniu z 2003 r., mimo istotnego znaczenia praktycznego, po początkowych wątpliwościach były przez notariuszy stosowane niejako bezrefleksyjnie, w myśl zasady rozstrzygania wszelkich wątpliwości na rzecz poddania dokumentowanej czynności prawnej reżimowi u.k.u.r., tj. przyznania ANR prawa pierwokupu lub prawa nabycia w odniesieniu do nieruchomości będącej przedmiotem dokumentowanej czynności. Wejście w życie noweli u.k.u.r. z 2016 r., rewolucjonizującej dotychczasowy model obrotu nieruchomościami rolnymi, postawiło notariuszy przed nowymi wyzwaniami, wobec których często okazują się oni bezradni. Warto więc prześledzić te regulacje u.k.u.r., które budzą największe wątpliwości w praktyce notarialnej, i wskazać niekorzystne rozwiązania praktyczne, do których prowadzi stosowanie tej ustawy.

Najbardziej problematyczna pozostaje kwestia indywidualizacji nieruchomości rolnej na potrzeby obrotu, a więc stosowania legalnej definicji zawartej w art. 2 pkt 1 u.k.u.r. Zadanie to ustawodawca nałożył przede wszystkim na notariuszy, często niemających w tym względzie odpowiedniego przygotowania teoretycznego ${ }^{28}$ ani stosownych instrumentów praktycznych. Pomimo niezwykle bogatej literatury poświęconej pojęciu nieruchomości rolnej ${ }^{29}$ określenie w konkretnym przypadku, czy dana nieruchomość

${ }^{26}$ Por. np. niezwykle udaną konferencję zorganizowaną 26 listopada 2020 r. przez Zakład Prawa Rolnego, Żywnościowego i Ochrony Środowiska Wydziału Prawa i Administracji Uniwersytetu im. Adama Mickiewicza w Poznaniu oraz Izbę Notarialną w Poznaniu pt. „Obrót nieruchomościami rolnymi - teoria i praktyka".

${ }^{27}$ P.A. Blajer, Neue Regelungen über den Grundstücksverkehr in Polen: Rückkehr in die Vergangenheit?, „Przegląd Prawa Rolnego” 2016, nr 1, s. 65-79.

${ }^{28}$ Notariusze w Polsce często są absolwentami uczelni, na których nie prowadzi się wykładów ani konserwatoriów z prawa rolnego lub zajęcia te mają jedynie charakter fakultatywny; nie mają więc możliwości zapoznania się w toku studiów uniwersyteckich z podstawowymi problemami tej dziedziny prawa. Na wynikające stąd negatywne konsekwencje zwraca uwagę R. Budzinowski, Prawo rolne wczoraj i dziś, w: A. Niewiadomski, K. Marciniuk, P. Litwiniuk (red.), Z zagadnień systemu prawa. Księga jubileuszowa Profesora Pawła Czechowskiego, Warszawa 2021.

29 Zob. zwłaszcza: B. Wierzbowski, Pojęcie nieruchomości rolnej w prawie polskim, „Studia Iuridica Agraria” 2005, t. IV, s. 96 i n.; W. Fortuński, M. Kupis, Pojęcie nieruchomości rolnej i gospodarstwa rolnego z uwzględnieniem wybranego orzecznictwa, „Nowy Przegląd Notarialny” 2019, nr 2, s. 37-50; K. Czerwińska-Koral, Pojęcie nieruchomości rolnej jako wyznacznik zasad obrotu nieruchomościami rolnymi, „Rejent” 2016, nr 6, s. 52-73; K. Marciniuk, Prawne instrumenty ingerencji władzy publicznej w obrót nieruchomościami rolnymi jako środek kształtowania 
gruntowa podlega reżimowi u.k.u.r. jako rolna, jest zadaniem skomplikowanym i ryzykownym. Wynika to z faktu, że wciąż znaczny obszar Polski nie jest objęty miejscowymi planami zagospodarowania przestrzennego, co zmusza notariuszy stosujących u.k.u.r. do oparcia się tylko na definicji nieruchomości rolnej zawartej w art. $46^{1}$ k.c. W świetle zaś tej definicji podstawowym kryterium wyodrębnienia nieruchomości rolnych są właściwości fizyko-chemiczne (agronomiczne) wierzchniej warstwy gleby pozwalające na uzyskiwanie płodów rolnych po zastosowaniu odpowiednich zabiegów agrotechnicznych. Chodzi zatem o agronomiczne cechy gruntu, które decydują o tym, czy uzyskiwanie na nim produktów rolnych jest fizycznie możliwe $^{30}$. W literaturze wskazuje się też, że z definicji nieruchomości rolnej zawartej w k.c. wynika, iż nieruchomość ta traci rolniczy charakter dopiero $\mathrm{z}$ chwilą faktycznego zagospodarowania gruntu, uniemożliwiającego dalsze wykorzystanie go do prowadzenia działalności rolniczej ${ }^{31}$. Innymi słowy, przy ocenie możliwości wykorzystania na cele rolnicze należy brać pod uwagę to, czy przy wykorzystaniu obecnej techniki może być ona włączona do procesu produkcji rolnej ${ }^{32}$. Przesłankę przeznaczenia gruntu na cele rolnicze (aktualnego i potencjalnego) należy oceniać w sposób obiektywny. Nie ma znaczenia subiektywne postrzeganie jej przez właściciela lub nabywcę nieruchomości. Zgodnie z wyrażonym w literaturze poglądem, jeżeli nieruchomość nie jest obecnie wykorzystywana na cele rolnicze, należy zbadać, czy w drodze zabiegów rekultywacyjnych możliwe jest uzyskanie stanu, w którym będzie ona zdatna do prowadzenia działalności rolniczej. W tym kontekście powinno się stosować kryterium racjonalnych nakładów. Trzeba zweryfikować, czy gdyby przystosowano nieruchomość do prowadzenia działalności rolniczej, osiągnięte rezultaty gospodarcze uzasadniałyby poniesione nakłady. Należałoby zatem porównać przychody, które mogłaby przynieść działalność rolnicza z wykorzystaniem nieruchomości,

ustroju rolnego, Białystok 2019, s. 76 i n.; Z. Truszkiewicz, Wplyw planowania przestrzennego na pojęcie nieruchomości rolnej w rozumieniu Kodeksu cywilnego, „Studia Iuridica Agraria” 2007, nr 6, s. 152 i n.; K. Marciniuk, Pojęcie nieruchomości rolnej jako przedmiotu reglamentacji obrotu własnościowego, „Studia Iuridica Lublinensia” 2017, t. XXVI, nr 1, s. 94 i n.; Z. Truszkiewicz, Nieruchomość rolna i gospodarstwo rolne w rozumieniu u.k.u.r., „Krakowski Przegląd Notarialny” 2016, nr 2, s. 139-172; P. Wojciechowski, Pojęcie nieruchomości rolnej, w: M. Korzycka (red.), Instytucje prawa rolnego, Warszawa 2019, s. 147 i n.; A. Suchoń, Pojęcie nieruchomości rolnej, gospodarstwa rolnego i działalności rolniczej w ustawie o ksztattowaniu ustroju rolnego - wybrane kwestie z praktyki notarialnej, „Przegląd Prawa Rolnego” 2019, nr 2, s. 91-111.

${ }^{30}$ A. Lichorowicz, Glosa do wyroku $S N$ z 2.06.2000 r. II CKN 1067/98, OSP 2001, nr 2, poz. 27 , s. 88 i n.

${ }^{31}$ Z. Truszkiewicz, Wplyw planowania ..., s. 150.

${ }^{32}$ P. Wojciechowski, Pojęcie nieruchomości rolnej..., s. 157. 
z ponoszonymi kosztami zabiegów rekultywacyjnych. Gdy koszty przekraczają przychody, nakładów nie można uznać za racjonalne. W przypadku zatem, gdy przy zastosowaniu odpowiednich zabiegów agrotechnicznych, według kryterium racjonalnych nakładów, można grunt przystosować do prowadzenia działalności rolniczej, należy uznać go za nieruchomość rolną (w rozumieniu art. 2 pkt 1 u.k.u.r. w zw. z art. $46^{1}$ k.c.). Jeżeli przesłanki te nie są spełnione, taki grunt nie stanowi nieruchomości rolnej i nie podlega przepisom ustawy o kształtowaniu ustroju rolnego ${ }^{33}$.

Nietrudno wskazać, że przytoczone wypowiedzi doktryny, w których do głosu dochodzą kryteria albo bardzo ocenne, albo wymagające wiedzy specjalistycznej, mają ograniczone znaczenie w rozstrzyganiu wątpliwości co do statusu nieruchomości w konkretnym przypadku. Wątpliwości tych nie rozwiewa także analiza orzecznictwa polskich sądów, które wykazuje tendencję do nader szerokiego definiowania nieruchomości rolnej w rozumieniu k.c. Wystarczy przytoczyć tezy postanowienia Sądu Najwyższego z 28 stycznia 1999 r. $^{34}$, w którym stwierdzono, że decydujące dla uznania nieruchomości za rolną jest przeznaczenie gruntu, a nie sposób, w jaki grunt jest faktycznie wykorzystywany. Przeznaczenia gruntu nie zmienia natomiast wyłączenie go z rolniczego wykorzystania, choćby na dłuższy okres, w następstwie czynności prawnych (najmu, dzierżawy, użyczenia) bądź określonych stanów faktycznych (składowanie maszyn, wydzielenie placu gier i zabaw), o ile ani w pierwszym, ani w drugim przypadku grunt nie traci trwale właściwości rolniczych. Nie traci też ich wówczas, gdy można je przywrócić w drodze stosowanych zabiegów, np. rekultywacyjnych. Tym samym, zdaniem Sądu Najwyższego, nieruchomość służąca przez lata potrzebom produkcji przemysłowej może mieć charakter rolny - ,poddana zabiegom rekultywacyjnym może być bowiem przywrócona do pierwotnego przeznaczenia, a w każdym razie może być wykorzystana przemysłowo-rolniczo". Jeszcze bardziej radykalny pogląd został wyrażony w wyroku Wojewódzkiego Sądu Administracyjnego w Poznaniu z 8 grudnia 2011 r. ${ }^{35}$ Sąd ten stwierdził, że nawet w sytuacji, gdy przez dłuższy okres nieruchomość zagospodarowana była w inny sposób i wykorzystywana do celów handlowo-usługowych czy produkcyjnych, niezwiązanych z produkcją rolną, to jeśli tylko istnieje możliwość wykorzystania jej do prowadzenia działalności wytwórczej w rolnictwie w zakresie produkcji roślinnej i zwierzęcej, nie można odmówić jej charakteru rolnego ${ }^{36}$.

${ }_{33}$ T. Czech, Ksztaltowanie ustroju rolnego. Komentarz, Warszawa 2020.

${ }^{34}$ Postanowienie SN z 28 stycznia 1999 r., III CKN 140/98, LEX nr 50652.

${ }^{35}$ Wyrok WSA w Poznaniu z 8 grudnia 2011 r., IV SA/Po 558/11, LEX nr 1154873.

${ }^{36}$ Warto jednak odnotować, że oba wymienione orzeczenia, często powoływane w literaturze na poparcie tezy o konieczności szerokiej interpretacji definicji nieruchomości rolnej, zostały 
Problemy praktyczne, przed którymi staje notariusz dążący do określenia statusu danej nieruchomości na potrzeby stosowania u.k.u.r., ukazuje również kwestia znaczenia zakwalifikowania jej jako gruntu rolnego w rozumieniu przepisów dotyczących katastru nieruchomości, w szczególności przepisu $§ 9$ rozporządzenia Ministra Rozwoju Pracy i Technologii z 27 lipca 2021 r. w sprawie ewidencji gruntów i budynków ${ }^{37}$. W tym względzie brakuje również jednolitego stanowiska w judykaturze i nauce prawa. $Z$ jednej strony dominuje obecnie pogląd, że o uzyskaniu lub utracie charakteru rolnego nieruchomości nie przesądza wpis (lub jego zmiana) w ewidencji gruntów i budynków, bowiem dane zawarte w tej ewidencji mają jedynie charakter informacyjny. W konsekwencji oparcie się na tych danych w praktyce może prowadzić do błędnych wniosków co do kwalifikacji danej nieruchomości jako nieruchomości rolnej (w rozumieniu art. $46^{1}$ k.c. i art. 2 pkt 1 u.k.u.r. ${ }^{38}$ ). Podobną perspektywę przyjmuje niekiedy judykatura, np. Naczelny Sąd Administracyjny w wyroku z 12 grudnia 2017 r. ${ }^{39}$ stwierdził, że dane ewidencyjne mają charakter informacyjno-techniczny i odnoszą się do konkretnej działki ewidencyjnej. Ewidencja rejestruje jedynie stany prawne wynikające $\mathrm{z}$ określonych dokumentów urzędowych, a zatem stany ustalane w innym trybie lub przez inne uprawnione organy orzekające. Dla obywateli i organów państwowych moc wiążącą mają tylko dane dotyczące opisu gruntów (ich położenia, granic, rodzaju użytków itp.). Ewidencja nie rozstrzyga natomiast sporów co do gruntów i budynków, a organy ewidencyjne nie są uprawnione do weryfikacji dokumentów, na podstawie których dokonują zmian w ewidencji. Ten pogląd znalazł również odzwierciedlenie w treści podstawowego dokumentu dla praktyki notarialnej w Polsce, tj. Wspólnego Stanowiska Ministerstwa Rolnictwa i Rozwoju Wsi, Krajowego Ośrodka Wsparcia Rolnictwa oraz Krajowej Rady Notarialnej z 27 lutego 2020 r. w sprawie stosowania w praktyce ustawy o kształtowaniu ustroju rolnego. Zgodnie $\mathrm{z}$ treścią tego dokumentu przy kwalifikowaniu nieruchomości jako rolnej pomocne mogą być dane z ewidencji gruntów i budynków. Jako pomocne nie mogą mieć zaś charakteru rozstrzygającego.

wydane na podstawie stanu faktycznego niezwiązanego ze stosowaniem regulacji u.k.u.r. Były to odpowiednio: kwestie związane ze zniesieniem współwłasności gospodarstwa rolnego na podstawie art. 213 i n. k.c. (postanowienie SN z 28 stycznia 1999 r., III CKN 140/98) oraz zagadnienia związane z przekształceniem prawa użytkowania wieczystego nieruchomości rolnej w prawo własności (wyrok WSA w Poznaniu z 8 grudnia 2011 r., IV SA/Po 558/11).

37 Rozporządzenie Ministra Rozwoju Pracy i Technologii z 27 lipca 2021 r. w sprawie ewidencji gruntów i budynków (Dz. U. poz. 1390).

${ }_{38}$ P. Wojciechowski, Pojęcie nieruchomości rolnej..., s. 157.

${ }^{39}$ Wyrok NSA z 12 grudnia 2017 r., I OSK 1174/17, LEX nr 2430459. 
$\mathrm{Z}$ drugiej strony $\mathrm{w}$ stosunkowo niedawnym orzecznictwie wyrażono przeciwny pogląd, zgodnie z którym dla ustalenia, że nieruchomość ma charakter rolny - bowiem może być wykorzystana do prowadzenia działalności wytwórczej w rolnictwie w zakresie produkcji roślinnej i zwierzęcej - rozstrzygające znaczenie ma rodzaj użytków ujawnionych w ewidencji gruntów ${ }^{40}$.

W konsekwencji na potrzeby praktyki notarialnej legalną definicję nieruchomości rolnej zawartą $\mathrm{w}$ u.k.u.r można uznać za precyzyjną jedynie w sytuacjach, gdy cały obszar danej nieruchomości objęty jest miejscowym planem zagospodarowania przestrzennego. Należy jednak podkreślić, że możliwość ta nie dotyczy całej powierzchni RP, a w konkretnym przypadku oznaczenie danej nieruchomości w planie zagospodarowania przestrzennego może budzić wątpliwości co do jej rolnej kwalifikacji. Wynika to z faktu, że treść planu nie zawsze jest jednoznaczna.

Przedstawione problemy z określeniem prawnego statusu danej nieruchomości na potrzeby stosowania u.k.u.r. prowadzą niekiedy notariuszy do przyjmowania rozwiązań zaskakujących i nie do końca racjonalnych. Tezę tę można zwłaszcza odnieść do nieruchomości o mieszanym charakterze, tj. nieruchomości obejmujących obok gruntów nadających się do wykorzystania rolniczego także grunty o innym sposobie użytkowania. W tym względzie istnieje tendencja do nieco bezrefleksyjnego podążania za sformułowaniami zawartymi w uzasadnieniu wyroku Sądu Najwyższego z 5 września 2012 r. ${ }^{41}$, w którym stwierdzono, że w okolicznościach konkretnej rozpatrywanej przez niego sprawy nieruchomość powinna podpadać w całości pod uregulowania u.k.u.r., jeśli nie jest w całości wykorzystywana i przeznaczona na cele inne niż rolne. Zdaniem Sądu Najwyższego stanowisko to w tej konkretnej sprawie w najwyższym stopniu odpowiadało zasadzie pewności obrotu. Powszechna akceptacja tej tezy skutkuje w praktyce obrotu tendencją do jak najszerszego interpretowania pojęcia „nieruchomość rolna”. Zwolennicy takiego podejścia, powołując się na „,bezpieczeństwo obrotu”, argumentują, że w razie wątpliwości co do rolnej kwalifikacji nieruchomości z uwagi na art. 2 pkt 1 u.k.u.r. nieruchomość tę należy poddać reżimowi przewidzianemu $\mathrm{w}$ wymienionym akcie prawnym.

Tymczasem w obecnym stanie prawnym, inaczej niż miało to miejsce przed wejściem w życie noweli u.k.u.r. z 2016 r., bezrefleksyjna akceptacja wyżej opisanego, „ostrożnościowego” stanowiska pociąga za sobą istotne konsekwencje praktyczne, w szczególności dla nabywcy nieruchomości za-

${ }^{40}$ Wyrok NSA z 12 marca 2020 r., II OSK 1279/18, LEX nr 3020156.

${ }^{41}$ Wyrok SN z 5 września 2012 r., IV CSK 93/12. 
kwalifikowanej przez notariusza jako rolna. Nabywcę takiej nieruchomości obciążają bowiem obowiązki określone w art. $2 \mathrm{~b}$ u.k.u.r., w tym obowiązek prowadzenia gospodarstwa rolnego, w skład którego weszła nabyta nieruchomość, przez 5 lat od nabycia. Sankcją za uchybienie temu obowiązkowi jest natomiast możliwość wystąpienia przez KOWR do sądu o nabycie własności tej nieruchomości przez KOWR działający na rzecz Skarbu Państwa, za zapłatą ceny odpowiadającej jej wartości rynkowej (art. 9 ust. 3 u.k.u.r.). Okoliczność ta ma istotne znaczenie w przypadkach, w których pojawiają się wątpliwości co do rolnego charakteru nabywanej nieruchomości, a w rzeczywistości jest ona nabywana w celach inwestycyjnych.

Praktyka obrotu dostarcza dalszych przykładów nieporozumień w zakresie stosowania przez notariuszy definicji nieruchomości rolnej wynikającej z u.k.u.r., związanych z występowaniem w obrocie nieruchomości o mieszanym charakterze. Wystarczy wymienić dość często stosowany zabieg polegający na poddawaniu odrębnemu reżimowi prawnemu części nieruchomości objętych tą samą księgą wieczystą, np. wydzielonych działek geodezyjnych. Sytuacja ta ma miejsce zarówno w przypadku, gdy jedna część nieruchomości (tj. działka) kwalifikowana jest jako rolna, druga zaś jako nierolna, jak i w przypadku, gdy jedna część nieruchomości kwalifikowana jest jako rolna, a druga jako leśna, w rozumieniu przepisów ustawy z 28 września $1991 \mathrm{r}$. o lasach ${ }^{42}$. W opisanej sytuacji części tej samej nieruchomości, zarówno w rozumieniu wieczystoksięgowym, jak i cywilistycznym (art. 46 k.c.), zbywane są z zastosowaniem odrębnych reżimów prawnych. Rozwiązanie to - choć jego celem jest zapobieżenie sytuacjom, by szczególne regulacje prawnorolne znajdowały zastosowanie do nieruchomości rolnych tylko w części, i to często nieznacznej, należy jednak poddać krytyce. Podważa ono bowiem znaczenie ksiąg wieczystych jako instrumentu indywidualizującego nieruchomość na potrzeby obrotu (art. 1 ustawy z 6 lipca 1982 r. o księgach wieczystych i hipotece ${ }^{43}$ ), jak również pomija fakt, że każda nieruchomość rolna w rozumieniu art. $46^{1} \mathrm{k}$.c. jest jednocześnie nieruchomością gruntową w rozumieniu art. 46 tego aktu prawnego. W praktyce stosowanie tego rozwiązania niejednokrotnie przynosi rezultaty sprzeczne $\mathrm{z}$ wolą stron dokumentowanej przez notariusza czynności.

Nie tylko interpretacja pojęcia nieruchomości rolnej - kluczowego dla tradycyjnego rolnego prawa gruntowego - stanowi obecnie wyzwanie dla stosujących u.k.u.r. notariuszy. Taki sam problem wywołuje rozumienie pojęcia gospodarstwa rolnego (art. 2 pkt 2 u.k.u.r.), przede wszystkim z uwagi

${ }^{42}$ Ustawa z 28 września 1991 r. o lasach (t.j. Dz. U. z 2021 r., poz. 1275 ze zm.).

${ }^{43}$ Ustawa z 6 lipca 1982 r. o księgach wieczystych i hipotece (t.j. Dz. U. z 2019 r., poz. 2204 ze zm.). 
na fakt, że definicja z u.k.u.r. odsyła do definicji rolniczej jednostki produkcyjnej zawartej w art. $55^{3}$ k.c. By unaocznić skalę problemu, wystarczy wspomnieć, że w praktyce współczesnego obrotu pojęcie gospodarstwa rolnego wydaje się wciąż rozumiane w kategoriach definicji zawartej w $\S 2$ ust. 1 rozporządzenia Rady Ministrów z 28 listopada 1964r. w sprawie przenoszenia własności nieruchomości rolnych, znoszenia współwłasności takich nieruchomości oraz dziedziczenia gospodarstw rolnych ${ }^{44}$, jako wszystkie należące do tej samej osoby nieruchomości rolne, jeżeli stanowią lub mogą stanowić zorganizowaną całość gospodarczą, wraz z pozostałymi składnikami gospodarstwa. W konsekwencji pomija się w praktyce dorobek doktryny prawa rolnego, dążącej do wyjaśnienia natury gospodarstwa rolnego w rozumieniu art. $55^{3} \mathrm{k}$.c., poprzez podkreślenie w ramach tej konstrukcji znaczenia elementów funkcjonalnych ${ }^{45}$.

Nieporozumieniom wokół pojęcia gospodarstwa rolnego na płaszczyźnie u.k.u.r. towarzyszą obecnie jeszcze ważniejsze dla praktyki wątpliwości związane z rozumieniem nałożonego na nabywcę nieruchomości rolnej obowiązku prowadzenia gospodarstwa rolnego, w skład którego weszła nabyta nieruchomość - przez 5 lat od nabycia (art. 2 b ust. 1 u.k.u.r.) ${ }^{46}$. Niejasna pozostaje sama treść tego obowiązku, jego znaczenie w ramach rodzinnego obrotu nieruchomościami rolnymi, możliwość jego pogodzenia ze słusznymi prawami dzierżawcy lub użytkownika nabywanej nieruchomości ${ }^{47}$. Powyższe trudności nabierają ponadto znaczenia w kontekście sankcji wywłaszczeniowej za uchybienie temu obowiązkowi, przewidzianej w art. 9 ust. 3 u.k.u.r.

Wszystkie te okoliczności sprawiają, że wzrost praktycznego znaczenia regulacji prawnorolnych, który nastąpił w 2016 r. w związku z nowelizacją u.k.u.r., nie tylko istotnie wpłynął na działalność notariuszy, ale także przyczynił się do pojawienia się różnego rodzaju ryzyk dla przedstawicieli tego zawodu. Ryzyka te w szczególności odnoszą się do prawdopodobieństwa dokonania błędnych ustaleń w zakresie identyfikowania danej nieruchomości jako rolnej na potrzeby obrotu lub ustalania faktu obowiązywania nakazów

${ }^{44}$ Rozporządzenie Rady Ministrów z 28 listopada 1964r. w sprawie przenoszenia własności nieruchomości rolnych, znoszenia współwłasności takich nieruchomości oraz dziedziczenia gospodarstw rolnych (Dz. U. Nr 45, poz. 304).

${ }^{45}$ Por. R. Budzinowski, Pojęcie gospodarstwa rolnego wedlug Kodeksu cywilnego (rozważania na tle art. $55^{3}$ k.c.), „Ruch Prawniczy, Ekonomiczny i Socjologiczny” 1991, nr 3; idem, Gospodarstwo rolne i przedsiębiorstwo rolne, w: A. Stelmachowski (red.), Prawo rolne, Warszawa 2005, s. 114.

46 D. Łobos-Kotowska, Prawne pojęcie osobistego prowadzenia gospodarstwa rolnego, „Przegląd Prawa Rolnego” 2021, nr 1, s. 89-106.

47 Szerzej: P.A. Blajer, Z prawnej problematyki obowiązów..., s. 33 i n. 
i zakazów wynikających z art. $2 b$ ust. 1 u.k.u.r., które to błędy sankcjonowane są tylko w jeden sposób - nieważnością dokumentowanej czynności. Stanowi to zagrożenie dla stosujących u.k.u.r. notariuszy, potencjalnie narażając ich na odpowiedzialność związaną z nader restrykcyjną i często nieuzasadnioną interpretacją przez instytucje państwowe obowiązków przedstawicieli tego zawodu wynikających z art. 80 § 2 i 81 ustawy z 14 lutego 1991 r. - Prawo o notariacie ${ }^{48}(\mathrm{tj}$. obowiązku czuwania nad należytym zabezpieczeniem praw i słusznych interesów stron oraz innych osób, dla których czynność ta może powodować skutki prawne, jak również obowiązku odmowy dokonania czynności notarialnej sprzecznej z prawem).

\section{Podsumowanie}

Przedstawione rozważania nie pozwalają niestety na wysnucie optymistycznych wniosków co do skutków obserwowanej od 2016 r. „ofensywy” regulacji prawnorolnych, związanej z nowelizacją u.k.u.r. Zwraca uwagę okoliczność, że proces ten nie następuje w sposób racjonalny i spójny. Jednocześnie rozważania te przemawiają na rzecz formułowanego w literaturze postulatu upowszechnienia nauczania prawa rolnego na uczelniach wyższych ${ }^{49}$. Szersza edukacja w tym zakresie wydaje się bowiem niezbędna, zarówno z punktu widzenia osób stosujących prawo, jak i to prawo stanowiących. Pożądanym jej efektem byłoby zwłaszcza bardziej systemowe podejście do regulacji rolnego prawa gruntowego, umożliwiające dopasowanie ich do polskiego systemu prawa par excellence.

Przeprowadzone analizy wykazały też, że fundamentalne dla tradycyjnego prawa rolnego terminy, takie jak: nieruchomość rolna, gospodarstwo rolne lub działalność rolnicza, wciąż nie doczekały się precyzyjnego, nowoczesnego ujęcia na płaszczyźnie polskich aktów prawnych. Przeciwnie, ich legalne definicje są anachroniczne i nieprecyzyjne, mimo że w doktrynie prawa rolnego zostały one teoretycznie dopracowane, w czym także należy podkreślić znaczenie dorobku Szanownego Jubilata. Uprawniony wydaje się wniosek, że jeśli polski ustawodawca przystąpi w przyszłości do opracowania nowoczesnej ustawy o kształtowaniu ustroju rolnego - ponieważ trudno za taką uznawać obecnie obowiązującą u.k.u.r. ${ }^{50}$ - to inspiracji dla zawartych

48 Ustawa z 14 lutego 1991 r. - Prawo o notariacie (t.j. Dz. U. z 2020 r., poz. 1192 ze zm.).

49 Por. R. Budzinowski, O potrzebie nauczania prawa rolnego, „Przegląd Prawa Rolnego” 2010, nr 1, s. 147 i n.

${ }^{50}$ Regulacje u.k.u.r., pomimo wprowadzającej w błąd treści preambuły i art. 1 tego aktu prawnego, koncentrują się bowiem na publicznoprawnej reglamentacji obrotu nieruchomościa- 
w niej rozwiązań powinien poszukiwać w publikacjach Profesora Romana Budzinowskiego. Na ich podstawie będzie bowiem w stanie przygotować akt prawny, którego regulacje będą odnosiły się do nowocześnie i wieloaspektowo rozumianej działalności rolniczej, zapewniając odpowiednie gwarancje i przywileje dla podmiotów rzeczywiście ją prowadzących ${ }^{51}$.

\section{BIBLIOGRAFIA}

Balwicka-Szczyrba M. (2018), O nabywaniu własności nieruchomości rolnych $w$ drodze zasiedzenia, „Gdańskie Studia Prawnicze” t. XXXIX.

Balwicka-Szczyrba M. (2020), Przesłanki nabycia nieruchomości rolnej w drodze zasiedzenia a ustrój wspólności majątkowej matżeńskiej, „Rejent” $\mathrm{nr} 8$.

Bidziński M., Chmaj M., Ulijasz B. (2017), Ustawa o wstrzymaniu sprzedaży nieruchomości Zasobu Wtasności Rolnej Skarbu Państwa - aspekt konstytucyjnoprawny, Torun.

Bieluk J. (2019), Przeksztatcenia spółek kapitałowych a ustawa o kształtowaniu ustroju rolnego, „Przegląd Prawa Rolnego” nr 2.

Bieluk J. (2021), Zastaw na udziałach $i$ akcjach w spótkach będacych właścicielami lub użytkownikami wieczystymi nieruchomości rolnych - paradoks art. 3 a ust. 3 a ustawy o kształtowaniu ustroju rolnego, „Przegląd Prawa Rolnego” nr 1.

Bieranowski A. (2016), Dekompozycja konstrukcji zasiedzenia w nowym reżimie ograniczeń nabycia własności nieruchomości rolnej-zagadnienia węzłowe i uwagi de lege ferenda, „Rejent” nr 5.

Biernat J. (2018), Nabywanie nieruchomości rolnych $w$ drodze zasiedzenia. Wybrane zagadnienia konstrukcyjne, „Studia Prawnicze. Rozprawy i Materiały” nr 1.

Blajer P.A. (2016), Neue Regelungen über den Grundstücksverkehr in Polen: Rückkehr in die Vergangenheit?, „Przegląd Prawa Rolnego” nr 1.

Blajer P.A. (2021), Z prawnej problematyki obowiazków nabywcy nieruchomości rolnej wynikajacych z art. $2 b$ ustawy o ksztattowaniu ustroju rolnego, „Przegląd Prawa Rolnego" nr 1 .

Budzinowski R. (1985), Zbycie spadku obejmujacego gospodarstwo rolne w praktyce notarialnej, „Nowe Prawo" nr 7-8.

mi rolnymi. Należałoby zatem postulować stosowną zmianę tytułu ustawy, tak by rzeczywiście odpowiadał on jej treści. Por. A. Lichorowicz, Instrumenty oddziaływania na strukture gruntowa Polski w ustawie z dnia 11 kwietnia 2003 r. o ksztaltowaniu ustroju rolnego, „Kwartalnik Prawa Prywatnego" 2004, z. 2, s. 387 i n.

${ }^{51}$ Por. R. Budzinowski, W kwestii statusu prawnego gospodarstwa rolnego jako przedsiębiorstwa, w: J. Jacyszyn, A. Dańko Roesler, M. Pazdan, W. Popiołek (red.), Rozprawy z prawa prywatnego. Księga pamiatkowa dedykowana Profesorowi Aleksandrowi Oleszce, Warszawa 2012; idem, Prawne pojęcie działalności rolniczej, „Prawo i Administracja” 2003, t. II, s. 167; idem, Nowa definicja przedsiębiorcy rolnego we włoskim kodeksie cywilnym, „Studia Iuridica Agraria” 2002, t. III; idem, Problemy ogólne ...; idem, Zmiany prawa rolnego. Tendencje rozwoju, „Ruch Prawniczy, Ekonomiczny i Socjologiczny” 2002, nr 2; idem, Status prawny rolnika jako przedsiębiorcy. Zagadnienia wybrane, „Ruch Prawniczy, Ekonomiczny i Socjologiczny” 2002, nr 3; idem, Koncepcja gospodarstwa rolnego... 
Budzinowski R. (1986), Umowa przekazania gospodarstwa rolnego nastepcy $w$ praktyce notarialnej, „Nowe Prawo” z. 7-8.

Budzinowski R. (1991), Pojęcie gospodarstwa rolnego wedtug Kodeksu cywilnego (rozważania na tle art. $55^{3}$ k.c.), „,Ruch Prawniczy, Ekonomiczny i Socjologiczny” nr 3.

Budzinowski R. (1992), Koncepcja gospodarstwa rolnego w prawie rolnym, Poznań.

Budzinowski R. (2002), Nowa definicja przedsiębiorcy rolnego we włoskim kodeksie cywilnym, „Studia Iuridica Agraria” t. III.

Budzinowski R. (2002), Status prawny rolnika jako przedsiębiorcy. Zagadnienia wybrane, „Ruch Prawniczy, Ekonomiczny i Socjologiczny” nr 3.

Budzinowski R. (2002), Zmiany prawa rolnego. Tendencje rozwoju, „Ruch Prawniczy, Ekonomiczny i Socjologiczny" nr 2.

Budzinowski R. (2003), Prawne pojęcie działalności rolniczej, „Prawo i Administracja” t. II.

Budzinowski R. (2004), Przekazanie gospodarstwa rolnego za rente strukturalna w praktyce notarialnej, „Rejent” nr 10.

Budzinowski R. (2005), Gospodarstwo rolne i przedsiębiorstwo rolne, w: A. Stelmachowski (red.), Prawo rolne, Warszawa.

Budzinowski R. (2008), Problemy ogólne prawa rolnego. Przemiany podstaw legislacyjnych i koncepcji doktrynalnych, Poznań.

Budzinowski R. (2010), O potrzebie nauczania prawa rolnego, „Przegląd Prawa Rolnego” nr 1.

Budzinowski R. (2012), W kwestii statusu prawnego gospodarstwa rolnego jako przedsiębiorstwa, w: J. Jacyszyn, A. Dańko Roesler, M. Pazdan, W. Popiołek (red.), Rozprawy z prawa prywatnego. Ksiega pamiatkowa dedykowana Profesorowi Aleksandrowi Oleszce, Warszawa.

Budzinowski R. (2021), Prawo rolne wczoraj i dziś, w: A. Niewiadomski, K. Marciniuk, P. Litwiniuk (red.), Z zagadnień systemu prawa. Ksiega jubileuszowa Profesora Pawła Czechowskiego, Warszawa.

Buszmak D., Kocot W. (2017), Przekształcenie spółki handlowej będącej właścicielem nieruchomości rolnej, „Przegląd Prawa Handlowego” nr 7.

Byczko Sz. (2017), Ustawowe prawo pierwokupu udziałów i akcji spótek będących właścicielami nieruchomości rolnych, w: P. Księżak, J. Mikołajczyk (red.), Nieruchomości rolne w praktyce notarialnej, Warszawa.

Czech T. (2020), Ksztaltowanie ustroju rolnego. Komentarz, Warszawa.

Czerwińska-Koral K. (2016), Pojęcie nieruchomości rolnej jako wyznacznik zasad obrotu nieruchomościami rolnymi, ,Rejent” $\mathrm{nr} 6$.

Fortuński W., Kupis M. (2019), Pojęcie nieruchomości rolnej i gospodarstwa rolnego z uwzględnieniem wybranego orzecznictwa, „Nowy Przegląd Notarialny” nr 2.

Gniewek E. (2017), Nieruchomość rolna jako przedmiot egzekucji, „Rejent” nr 7.

Grykiel J. (2016), Ograniczenia obrotu nieruchomościami rolnymi oraz prawami udziatowymi w spółkach po nowelizacji ustawy o ksztattowaniu ustroju rolnego, „Monitor Prawniczy" nr 12.

Lichorowicz A. (2001) Glosa do wyroku SN z 2.06.2000 r., II CKN 1067/98, OSP nr 2, poz. 27. Lichorowicz A. (2004), Instrumenty oddziaływania na strukturę gruntowa Polski w ustawie $z$ dnia 11 kwietnia 2003 r. o ksztaltowaniu ustroju rolnego, „Kwartalnik Prawa Prywatnego" z. 2.

Łobos-Kotowska D. (2021), Prawne pojęcie osobistego prowadzenia gospodarstwa rolnego, „Przegląd Prawa Rolnego" nr 1. 
Marciniuk K. (2017), Pojęcie nieruchomości rolnej jako przedmiotu reglamentacji obrotu wtasnościowego, „Studia Iuridica Lublinensia” t. XXVI, nr 1.

Marciniuk K. (2019), Prawne instrumenty ingerencji władzy publicznej w obrót nieruchomościami rolnymi jako środek kształtowania ustroju rolnego, Białystok.

Marszałkowska-Krześ E., Gil I. (2017), Wpływ wszczęcia postępowań restrukturyzacyjnych na obrót nieruchomościami rolnymi, w: P. Księżak, J. Mikołajczyk (red.), Nieruchomości rolne $w$ praktyce notarialnej, Warszawa.

Muszalska M. (2020), Spółki handlowe a znowelizowana ustawa o ksztaltowaniu ustroju rolnego - uwagi z praktyki notarialnej, „Studia Prawa Publicznego” nr 4.

Pisuliński J. (2016), O niektórych osobliwościach obrotu nieruchomościami rolnymi, „Rejent" nr 5.

Stranz J. (2016), Wplyw nowelizacji ustawy o ksztaltowaniu ustroju rolnego na procedure podwyższania kapitału zakładowego spółki akcyjnej, „Przegląd Prawa Handlowego” nr 12.

Suchoń A. (2019), Pojęcie nieruchomości rolnej, gospodarstwa rolnego i działalności rolniczej w ustawie o ksztaltowaniu ustroju rolnego - wybrane kwestie z praktyki notarialnej, „Przegląd Prawa Rolnego" nr 2.

Szereda A.J. (2016), Problematyka orzeczenia sądu w ustawie o ksztaltowaniu ustroju rolnego, „Krakowski Przegląd Notarialny” nr 4.

Truszkiewicz Z. (2007), Wpływ planowania przestrzennego na pojęcie nieruchomości rolnej w rozumieniu Kodeksu cywilnego, „Studia Iuridica Agraria” nr 6.

Truszkiewicz Z. (2016), Nieruchomość rolna i gospodarstwo rolne $w$ rozumieniu u.k.u.r., „Krakowski Przegląd Notarialny” nr 2.

Truszkiewicz Z. (2017), O kilku podstawowych zagadnieniach na tle ustawy o ksztaltowaniu ustroju rolnego (część II), „Rejent” nr 11.

Truszkiewicz Z. (2017), Zakres stosowania ustawy o ksztaltowaniu ustroju rolnego po nowelizacji z 2016 r., „Rejent” nr 7.

Wierzbowski B. (2005), Pojęcie nieruchomości rolnej w prawie polskim, „Studia Iuridica Agraria" t. IV.

Wojciechowski P. (2019), Pojęcie nieruchomości rolnej, w: M. Korzycka (red.), Instytucje prawa rolnego, Warszawa.

\title{
REFLECTIONS ON THE EXPANSION OF THE SCOPE OF AGRICULTURAL LAW REGULATION: A NOTARY'S PERSPECTIVE
}

\author{
Summary
}

The aim of the research conducted within the framework of this paper was to characterise the expansion of the scope of regulations classified as agricultural land law, resulting from the amendment to this Act on shaping the agricultural system of 2016, and its impact on the notarial practice of real estate trading. In the first part of the study, general issues presenting the scale of the impact of this Act on the regulations hitherto free from any form of "agrariarisation" (in particular, the traditional institutions of civil law, civil proceedings, company law and bankruptcy law) were analysed. In the second part of the paper, a practical dimension of 
the Act has been illustrated by an analysis of the problems that notaries as practitioners face when applying it in their everyday work. As part of the concluding remarks, an assessment of the expansion of the agricultural law regulation in the Polish legal system has been made, demonstrating that this process does not occur in a rational and coherent way.

Keywords: agricultural law, agricultural real estate, agricultural holding, shaping of agricultural system, notary

\title{
ALCUNE CONSIDERAZIONI RELATIVE ALL'AMPLIAMENTO NELL'AMBITO DELLE REGOLAZIONI DI DIRITTO AGRARIO - COMPRESA LA PROSPETTIVA DEL NOTAIO
}

\author{
Riassunto
}

L'articolo si propone, nei limiti della ricerca condotta, di caratterizzare il fenomeno che consiste nell'ampliare l'ambito di applicazione delle regolazioni che vanno annoverate nel diritto agrario fondiario, come consegue dalle modifiche apportate alla legge sul regime agricolo nel 2016, nonché l'impatto del fenomeno sulla pratica notarile nel trasferimento degli immobili. La prima parte del contributo analizza questioni di carattere generale che mettono in evidenza la portata dell'impatto avuto dalla legge su regolazioni finora libere di qualsiasi forma di "agrarizzazione", vale a dire, in particolare, istituti tradizionali di diritto civile, procedura civile, diritto societario e diritto fallimentare. La seconda parte illustra, invece, la dimensione pratica della legge, mettendo in luce alcuni problemi affrontati dai notai che in quanto professionisti la applicano svolgendo il lavoro di tutti i giorni. Nella parte conclusiva, si è cercato di valutare il fenomeno di ampliamento studiato nell'ordinamento giuridico polacco, cercando anche di far vedere che il processo in esame non viene svolto in modo razionale e coerente.

Parole chiave: diritto agrario, immobile agricolo, azienda agricola, regime agricolo, notaio 